\title{
Barriers to Smoking Cessation among Medical Students 2012-2013 Academic Year in the Faculty of Medicine, Universitas Padjadjaran
}

\author{
Reni Yuditha Kathrine, ${ }^{1}$ Elsa Pudji Setiawati, ${ }^{2}$ Lucky Saputra ${ }^{3}$ \\ ${ }^{1}$ Faculty of Medicine Universitas Padjadjaran, ${ }^{2}$ Department of Public Health Faculty of \\ Medicine Universitas Padjadjaran, ${ }^{3}$ Department of Psychiatry Faculty of Medicine, Universitas \\ Padjadjaran/Dr. Hasan Sadikin General Hospital Bandung
}

\begin{abstract}
Background: Smoking is one of leading various diseases and even death globally. It is often difficult for smokers to stop smoking, even those who work as a medical professional because there are some barriers around them. The objective of this study was to get an overview of the barriers to smoking cessation among smoker students of Faculty of Medicine, Universitas Padjadjaran.

Methods: A descriptive study was carried out to 62 medical students 2012-2013 academic year in the Faculty of Medicine, Universitas Padjadjaran. Before the respondents were selected, a survey using questionnaire was conducted to all medical students from the same academic year to determine their smoking status. A set of questions was developed, consisted of 4 components: physical or social, psychological or emotional, accessibility, and social contextual/life circumstances barriers to smoking cessation. The collected data were analyzed and presented in the form of percentages shown in the tables and figures.

Results: The most frequent barriers were from physical or social barriers (friends who smoke, 85\%), psychological or emotional barriers (fear of losing enjoyment, 71\%), barrier to access (lack of information about the way of smoking cessation, $42 \%$ ) and social contextual/life circumstances barriers (having other priorities other than to stop smoking, 71\%).

Conclusions: There are some barriers in medical students smokers make them difficult to stop smoking although they have more knowledge about health and the impact of smoking on health than other people. [AMJ.2015;2(3):352-58]
\end{abstract}

Keywords: Barriers, medical students, smoking cessation

\section{Introduction}

Smoking is a major public health problem as cigarette consumption contributes to the incidence of various disease and even death. ${ }^{1-3}$ This does not only affect the smokers themselves, but also people around them who unintentionally inhale cigarette smoke, known as passive smokers. Starting to smoke since an early age has been known having a significant effect in increasing the risk of death. ${ }^{4}$ The problems of smoking need more attention because it is a risk factor of four leading non communicable diseases in the world and a cause of death. In 2009, Indonesia placed the fourth ranked of the highest cigarette consumption. The cigarette consumption in that year was 260 billion. $^{1}$

Doctors play an important role to promote smoking cessation program. A little simple advice from a doctor to stop smoking and the example from himself by not smoking can be an effective tool and has a great potential to help patients to stop smoking. ${ }^{1}$ However, smoking behavior can also be seen at some doctors and it becomes a barrier in promoting smoking cessation programs for patients. Not just among doctors, smoking can also be found in medical students who actually will be a doctor in the future. ${ }^{1,5}$ Doctors should be free from smoking to be a role model for their patients, so that a medical student who smokes should be able to stop smoking before he/she becomes a doctor. Unfortunately, to stop smoking is not easy. ${ }^{6,7}$ This is because of some barriers that could be found around smokers. These barriers of smoking cessation are generally divided into 4 groups: physical or social, psychological or emotional, barriers to access programs/services/methods to

Correspondence: Reni Yuditha Kathrine, Faculty of Medicine, Universitas Padjadjaran, Jalan Raya Bandung-Sumedang Km.21, Jatinangor, Sumedang, Indonesia, Phone: +6287879464719 Email: reni.kathrine@gmail.com 
stop smoking and social contextual/life circumstances. ${ }^{8}$ By these barriers, it can be said that the program of smoking cessation is difficult to be successful. ${ }^{9}$

Based on what has been mentioned above, the author was interested in getting an overview of the barriers to smoking cessation in student smokers in the Faculty of Medicine, Universitas Padjadjaran. By knowing the barriers, the author hoped that smokers could choose the right approach in their attempt to stop smoking.

\section{Methods}

This study was a descriptive study with a cross-sectional approach and conducted on student smokers in the Faculty of Medicine, Universitas Padjadjaran. Respondents were obtained by doing survey first by distributing questionnaires to all medical students of the Faculty of Medicine, Universitas Padjadjaran, academic year 2012/2013 to determine their smoking status. From the survey, it was found a total population of 62 active smokers and they were taken as subjects for this study after being asked about their willingness to be respondents.

The respondents were then given a questionnaire that contains some questions about barriers to smoking cessation. They were asked to identify the barriers faced by them. The collected data has been processed and presented in the form of percentages shown in the tables and diagrams.

\section{Results}

Based on the sex characteristics, it was found that the male respondents (95\%) were more dominant than the female. Based on their residence, most of the respondents live in a boarding house/rented (76\%), not with their parents. Respondents were chosen from the first to fourth year college students. The most respondents are from the third (36\%) and four (34\%) year college students. The age of the respondents were ranged from 17 to 24 years old.

Age of first time smoking was divided

Table 1 Characteristics of Respondents

\begin{tabular}{|c|c|c|}
\hline Characteristics & Number (n) & Percentage (\%) \\
\hline \multicolumn{3}{|l|}{ Sex } \\
\hline Male & 59 & 95 \\
\hline Female & 3 & 5 \\
\hline \multicolumn{3}{|l|}{ Residence } \\
\hline House & 15 & 24 \\
\hline Boarding house/rented & 47 & 76 \\
\hline \multicolumn{3}{|l|}{ Grade of college } \\
\hline First year & 7 & 11 \\
\hline Second year & 12 & 19 \\
\hline Third year & 22 & 36 \\
\hline Fourth year & 21 & 34 \\
\hline \multicolumn{3}{|l|}{ Age (years old) } \\
\hline 17 & 1 & 2 \\
\hline 18 & 7 & 11 \\
\hline 19 & 11 & 18 \\
\hline 20 & 16 & 26 \\
\hline 21 & 15 & 24 \\
\hline 22 & 8 & 13 \\
\hline 23 & 1 & 2 \\
\hline 24 & 3 & 5 \\
\hline
\end{tabular}


Table 2 Age at First Smoking, Trial and Want to Stop Smoking

\begin{tabular}{lcc}
\hline & Number (n) & Percentage (\%) \\
\hline Age at First Smoking & 1 & 2 \\
$<10$ & 16 & 26 \\
$10-14$ & 33 & 53 \\
$15-19$ & 12 & 19 \\
$>19$ & & 89 \\
Ever tried to stop smoking? & 55 & 11 \\
Yes & 7 & 82 \\
No & & 18 \\
Want to stop smoking? & 51 & 11 \\
Yes & & \\
No & & \\
\hline
\end{tabular}

into four age groups (Table 2). The results of this study showed that most respondents tried cigarettes for the first time was at the age of 15-19 years (53\%), whereas, only one respondent started smoking for the first time at age $<10$ years.

Based on smoking cessation trial, $89 \%$ respondents said that they have tried to stop smoking. Meanwhile, $82 \%$ of respondents expressed that they want to stop smoking.

The results of this study showed that the most frequent physical or social barriers to smoking cessation was friends who smoke $(85 \%)$, followed by lack of friends support
(47\%).

The most frequent barrier from psychological or emotional factors was fear of losing enjoyment (71\%). Other barriers were the craving for cigarettes (65\%) and fear of failure in smoking cessation (53\%). Meanwhile, fear of gaining weight (5\%) was not stated as a barrier by many respondents.

Figure 3 about distribution of barrier to access, shows that $42 \%$ respondents had difficulty to stop smoking because they did not know how to stop smoking, 39\% respondents were not aware of any programs/ services for smoking cessation, $23 \%$ stated that the price

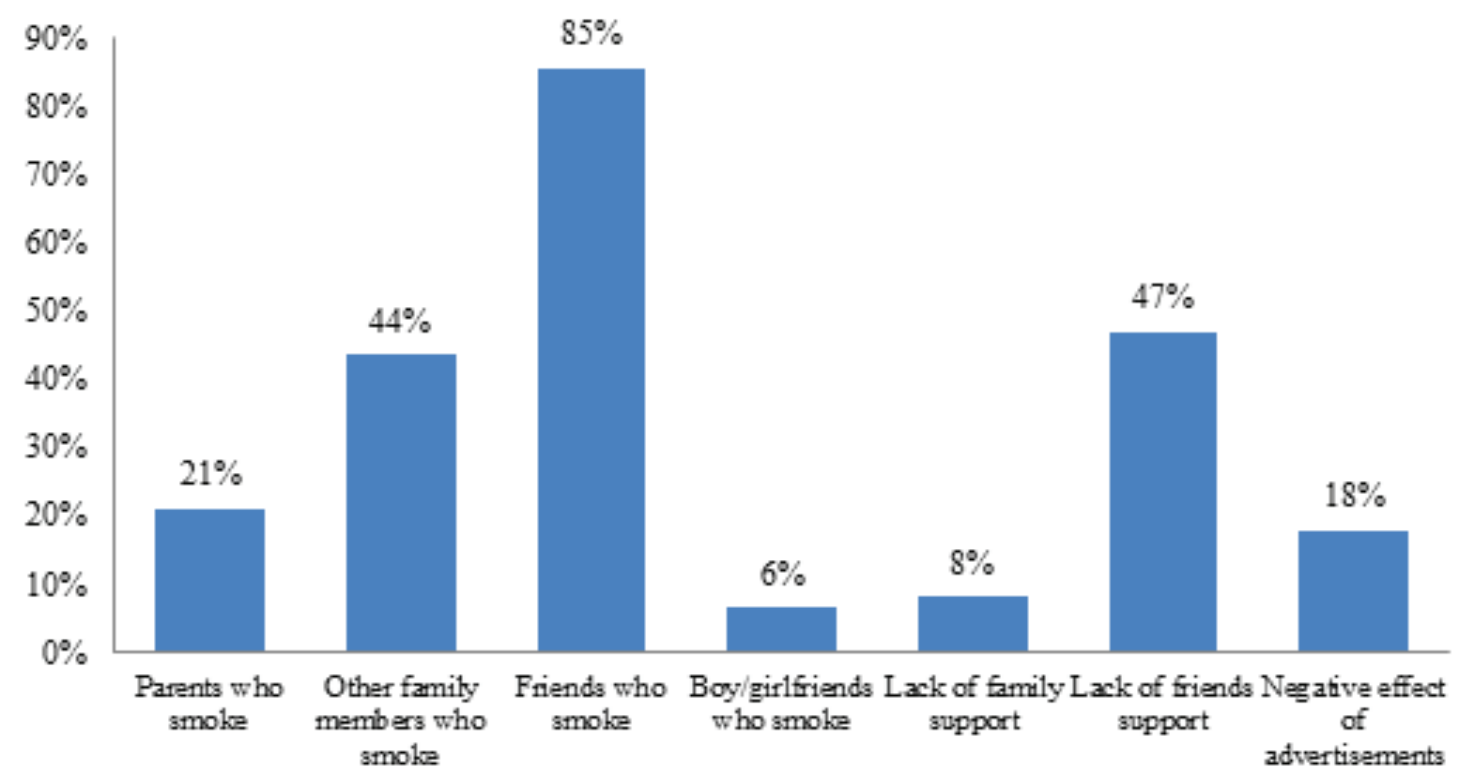

Figure 1 Distribution of Physical or Social Barriers in Respondents 


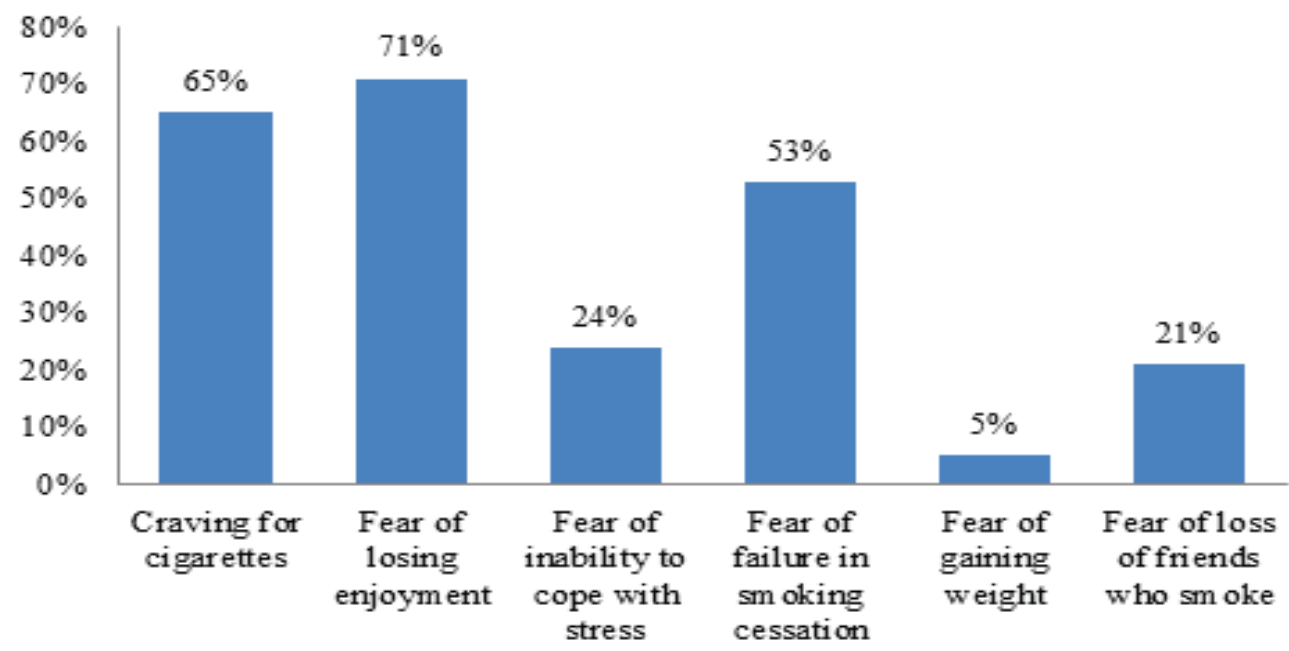

Figure 2 Distribution of Psychological or Emotional Barriers in Respondents

of the programs/services to stop smoking was too high for them, and $26 \%$ stated that they could not take smoking cessation class/ program because of their daily schedules.

Based on distribution of social contextual/ life circumstances barriers, $71 \%$ respondents had other priorities than stop smoking. Besides having other priorities, respondents expressed their discomfort about the environment where they live now (18\%). Because of their discomfort, they did not focus on smoking cessation.

\section{Discussions}

Table 1 show that the majority of respondents of this study were men (95\%). The majority of men among smokers also appeared in some studies or surveys, such as in the research conducted by Qidwai ${ }^{10}$ who stated that $96 \%$ of its respondents were men. Riset Kesehatan Dasar (Riskesdas) ${ }^{11}$ also noted that the majority of smokers in Indonesia were men. Based on their residence, most respondents (76\%) staying in boarding/rented room and not with their parents, were smokers. Living outside their own house was also contributed to the development of a person, especially in adolescence or young adulthood, associated with the supervision from family or parents and parental involvement in children activity. Parental supervision would help children in their development so it did not lead to negative behavior such as smoking. ${ }^{12}$

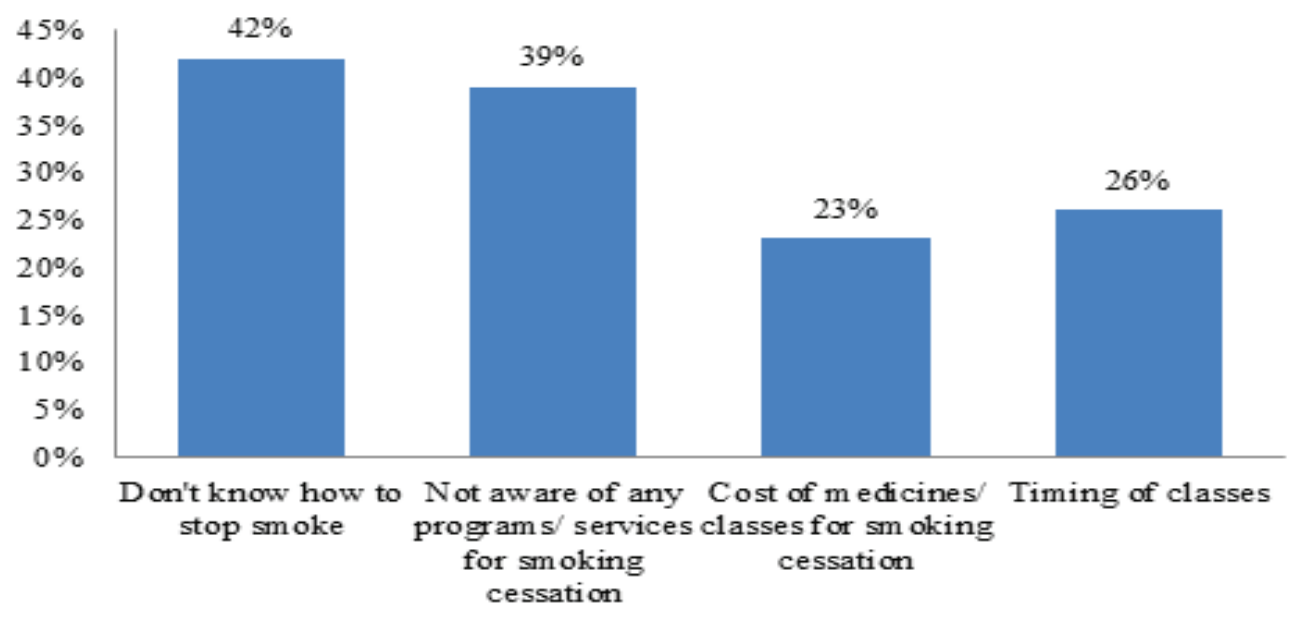

Figure 3 Distribution of Barriers to Access in Respondents 


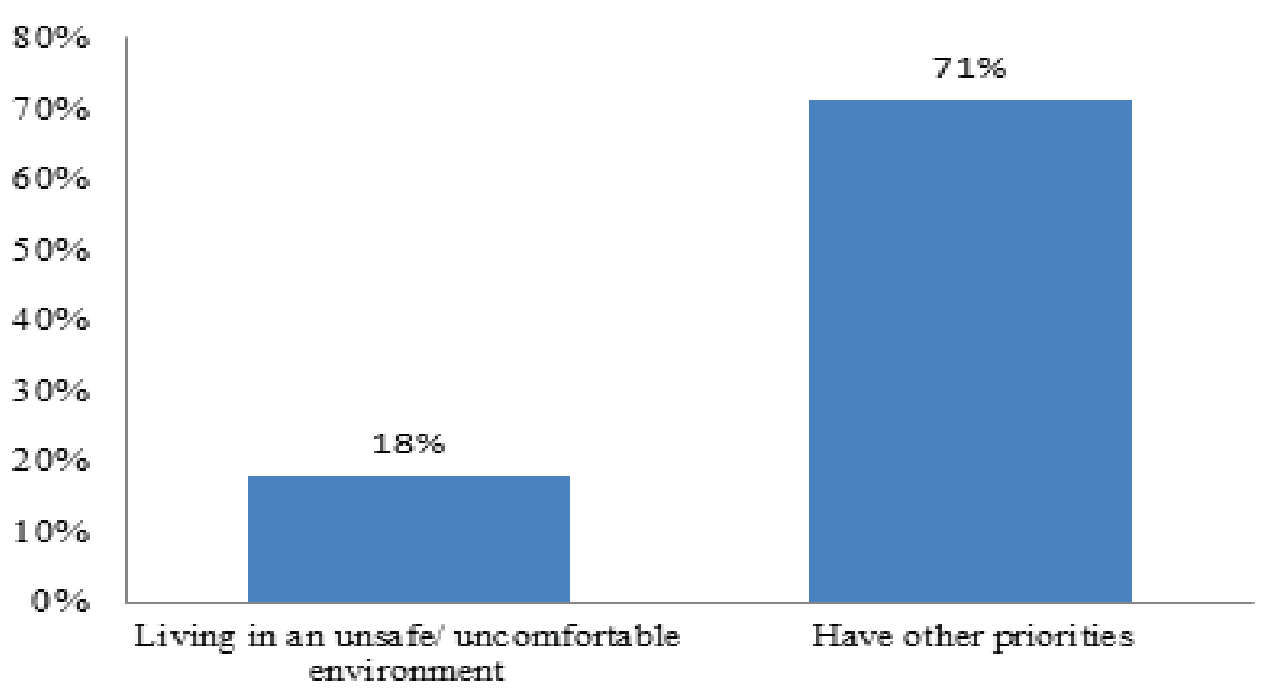

Figure 4 Distribution of Social Contextual/Life Circumstances Barriers in Respondents

According to the grade of college students, there were thirty-six percent respondents of third year college students and 34\% of forth year who were smokers. Even though the percentage of the third and fourth year were bigger that the first year (11\%) and the second year (19\%), it did not show any specific pattern as shown by Riskesdas surveys in $2010 .{ }^{11}$ Nevertheless, there was also a study which stated that smoking cessation increased along with education level of smokers. ${ }^{13}$

This study showed that the age at which most respondents try cigarettes for the first time was at 15-19 years old, occurring in 53\% respondents. Riskesdas (2010) also states the ages of 15-19 years old as the age group that the majority of Indonesian smokers started smoking. ${ }^{11}$

Eighty-nine percent of respondents have tried to stop smoking, but unfortunately they were failed or had a relapse so that at the moment when the study was conducted, their status were still smokers. The rate of smoking cessation itself was quite low and only a small number of smokers could stop smoking on his first attempt. The World Health Organization (WHO) ${ }^{7}$ and the research conducted by Paavola et al. ${ }^{14}$ figured that the rate of smoking cessation was only $2.5 \%$ per year. Desire of the respondents to stop smoking was also influenced by smoking cessation trials conducted by respondents. Those who had previously tried to stop smoking and experienced failure would have low confidence, afraid and lost the will to stop smoking. ${ }^{2,10,15}$

In terms of physical or social barriers, a friend who smokes and lack of friends support were expressed by respondents as barriers to smoking cessation for them. This is related to a study stating that smoking cessation occurred less in those whose friends were smokers. In that study, adolescent smokers expressed their own thought that the success of smoking cessation in young people can be improved if they had a friend who also wanted to stop smoking. The results showed that the success of smoking cessation in those whose best friend also smoked are more likely than those whose best friend was not a smoker. ${ }^{14}$ The motivation to stop smoking from friends, family, or couples who do not smoke could be a reason for a person to stop smoking. ${ }^{16}$

In terms of psychological or emotional barriers, $71 \%$ respondents expressed their pleasure for cigarettes and 65\% respondents expressed their addiction to cigarettes. Those reasons were barriers to smoking cessation. The enjoyment of cigarettes was obtained from substances found in cigarettes, the nicotine. This substance also had addictive properties. Administration of nicotine on the body could lead to tolerance and dependence. In the tolerance, dose response decreased so that when a smoker consumes cigarettes in his usual amount of consumption, he will not feel the effects of cigarettes he had expected. To get back the effects of cigarette, smokers have to increase the number of cigarettes consumed. ${ }^{3}$

Smoking can affect the levels of dopamine 
Reni Yuditha Kathrine, Elsa Pudji Setiawati, Lucky Saputra: Barriers to Smoking Cessation among Medical357 Students 2012-2013 Academic Year in the Faculty of Medicine, Universitas Padjadjaran

in someone's body which can give a pleasant effect and also amplify the effects of acetylcholine that affects the state of mind or mood, appetite, and memory. ${ }^{17}$ These pleasant effects can make a person feel able to cope with stress or problems in the life. Therefore, one of the reasons why it is hard for people to stop smoking is the fear of inability to cope with stress if they stop smoking. Fear of failure in smoking cessation trial could occur in smokers, especially in those who had experienced failure in smoking cessation trial previously. In the study, it was found that the confidence of people who had tried to stop smoking and failed was lower than those who had never tried. ${ }^{2,10,15}$

Another barrier was the barrier to access information (lack of information about the way of smoking cessation). Of these barriers, $42 \%$ respondents expressed they did not know how to stop smoking, and 39\% respondents expressed that they were not aware of any programs/services of smoking cessation. To overcome their ignorance of what they should do, there were actually existing programs/ services of smoking cessation that could help them. Unfortunately not all smokers knew of these programs/services. Other smokers have known that there were programs that could help them to stop smoking, but nevertheless, some still could not reach these programs both in terms of place, time, or financing.

The cost for the programs or price of medicine such as nicotine replacement agents was not cheap. In another study, smokers stated they were willing to take the program if it is covered by their health insurance., ${ }^{2,8,15}$ The Faculty of Medicine, Universitas Padjadjaran itself has already implemented a non-smoking area, but unfortunately the faculty has not provided program/services to help their students to stop smoking. Although there is no smoking cessation program on campus, a Smoking Cessation Clinic has already been established at the Community Health Center in Kopo, Bandung. In addition to Bandung, several hospitals in Jakarta also have a provided smoking cessation services. ${ }^{18-20}$

In terms of social contextual/ life circumstances barriers, $71 \%$ respondents stated that they had other priorities so that they were more concerned on those things than thinking of smoking cessation. Similarly, living in an unsafe or uncomfortable environment would make smokers prioritize overcoming the discomfort instead of focusing on smoking cessation. In general, social contextual/ life circumstances barriers make smoking cessation become a low priority for smokers. ${ }^{8}$

As a conclusion, there were some barriers in medical students which made them difficult to stop smoking, although they had more knowledge about health and the impact of smoking on health than the others. Therefore, the faculty is expected to help the students to stop smoking by providing information about smoking cessation and programs or services.

\section{References}

1. Eriksen M, MacKay J, Ross H. The tobacco atlas. 4th ed. Atlanta: American Cancer Society; 2012.

2. Minnesota Partnership for Action Against Tobacco (MPAAT), Blue Cross and Blue Shield of Minnesota (Blue Cross), Minnesota Department of Health. Quitting smoking: nicotine addiction in Minnesota. St. Paul: Minnesota Department of Health; 2001.

3. Lewis K. Smoking cessation. New York City: Oxford University Press; 2010.

4. Kenfield SA, Stampfer MJ, Rosner BA, Colditz GA. Smoking and smoking cessation in relation to mortality in women. JAMA. 2008;299(17):2037-47.

5. Abdullah AS, Qiming F, Pun V, Stillman FA, Samet JM. A review of tobacco smoking and smoking cessation practices among physicians in China: 1987-2010. Tob Control. 2011;22(1):9-14.

6. American Cancer Society. Guide to quitting smoking. 2012 [Cited 2012 May 8]; Available from: http://www. cancer.org/acs/groups/cid/documents / webcontent/002971-pdf.pdf.

7. WHO. Quitting tobacco. 2012 [Cited 2012 May 8]; Available from: http://www.who. int/tobacco/quitting/en.

8. Abrams DB, Niaura R. The tobacco dependence treatment handbook: aguide to best practices. New York City: Guilford Press; 2003.

9. Vaszar LT, Sarinas PSA, Lillington GA. Achieving tobaccocessation: currentstatus, current problems, future possibilities. Respiration. 2002;69(5):381-4.

10. Qidwai W. Barriers to smoking cessation: results of a survey among family practice patients.MEJFM [Online Journal]. 2004;5(5):1-12.

11. Badan Penelitian dan Pengembangan Kesehatan Kementerian Kesehatan RI. Riset Kesehatan Dasar 2010. Riskesdas; 2010 [Cited 2012 April 17]; Available from: 
http://www.riskesdas.litbang.depkes. go.id/download/TabelRiskesdas2010.pdf

12. Lowinson JH. Substance abuse: a comprehensive textbook. 4th ed. Philadelphia: Williams \& Wilkins; 2005.

13. Centers for Disease Control and Prevention. Quitting smoking among adults. MMWR. 2011;60(44):1513-9.

14. Paavola M, Vartiainen E, Puska P. Smoking cessation between teenage years and adulthood. Health Educ Res. 2001;16(1):49-57.

15. University of Wisconsin Center for Tobacco Research and Intervention. Barriers to quitting smoking. Madison: UW-CTRI; 2005.

16. Wiltshire S, Bancroft A, Parry O, Amos A. I came back here and started smoking again: perceptions and experiences of quitting among disadvantaged smokers. Health Educ Res. 2003;18(3):292-303.

17. Marc Galanter MD, Kleber EMGHD. The
American Psychiatric Publishing Textbook of Substance Abuse Treatment. 4th ed.Arlington: American Psychiatric Pub.; 2008.

18. Direktorat Jenderal Informasi dan Komunikasi Publik. Akibat perilaku warga, Bandung Sehat Terhambat. 2012 [Cited 13 December 2012];Available from: http://infopublik.kominfo.go.id/m/index. php?scr=read_news\&id=27634.

19. Rumah Sakit Royal Progress. Klinik paru dan pernapasan. 2010 [Cited 13 December 2012]; Available from: http://www. royalprogress.com/excellence.php?id=4\#.

20. Arman, SIM-RS Persahabatan. Pelayanan Khusus di RSUP Persahabatan. 2013 [downloaded 8 February 2013]. Available from: http://www.persahabatan.co.id/ index.php?option $=$ com_content $\&$ view=art icle\&id $=95 \&$ Itemid $=515$. 